\title{
Erratum
}

Ann Rehabil Med 2013;37(3):459

pISSN: 2234-0645 • eISSN: 2234-0653

http://dx.doi.org/10.5535/arm.2013.37.3.459

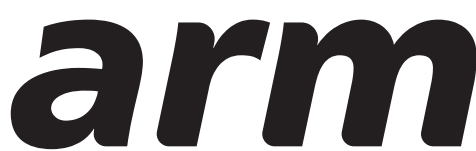

\section{Correction: The Effect of a Hand-Stretching Device During the Management of Spasticity in Chronic Hemiparetic Stroke Patients}

\author{
Eun Hyuk Kim, $\mathrm{MD}^{1}$, Min Cheol Jang, $\mathrm{MD}^{1}$, Jeong Pyo Seo ${ }^{1}$, \\ Sung Ho Jang, $\mathrm{MD}^{1}$, Jun Chan Song, $\mathrm{PhD}^{2}$, Hae Min Jo, $\mathrm{MD}^{1}$ \\ ${ }^{1}$ Department of Physical Medicine and Rehabilitation, Yeungnam University College of Medicine, Daegu; \\ ${ }^{2}$ Department of Physical Therapy, Daegu Health College, Daegu, Korea
}

http://dx.doi.org/10.5535/arm.2013.37.2.235

Ann Rehabil Med 2013;37(2):235-240

To the Editor,

We found that the second author name was published incorrectly. Min Cheol Jang was changed to Min Cheol Chang. We apologize for any inconvenience that this may have caused.

Yours sincerely,

Hae Min Jo

Corresponding author: Hae Min Jo

Department of Physical Medicine and Rehabilitation, Yeungnam University College of Medicine, 170 Hyeonchung-ro, Nam-gu, Daegu 705-717, Korea Tel: +82-53-620-3456, Fax: +82-53-625-3508, E-mail: jhm090@hanmail.net

(c) This is an open-access article distributed under the terms of the Creative Commons Attribution Non-Commercial License (http://creativecommons.org/ licenses/by-nc/3.0) which permits unrestricted noncommercial use, distribution, and reproduction in any medium, provided the original work is properly cited. Copyright $\odot 2013$ by Korean Academy of Rehabilitation Medicine 